\title{
Effect of organic manures on growth and yield of cashew cv. VENGURLA-4 under Konkan region of Maharashtra
}

R.C. GAJBHIYE, S. P. SALVI AND S. N. PAWAR

MEMBERS OF RESEARCH FORUM:

Corresponding author : R.C. GAJBHIYE, Regional Fruit Research Station, Vengurle, SINDHUDURG (M.S.) INDIA Email: rcgajbhiye@yahoo.com

Co-authors :

S.P. SALVI AND S. N. PAWAR, Regional Fruit Research Station, Vengurle, SINDHUDURG (M.S.) INDIA Email: salvisidhesh@rediffmail.com; shalanpawar1@gmail.com

\section{Summary}

Received : 05.03.2016; Revised : 12.04.2016; Accepted : 08.05.2016

An experiment on the effect of organic manures on growth and yield of cashew cv. VENGURLA4 under Konkan region of Maharashtra was conducted under AICRP-Cashew programme during 2011-12 to 2014-15 at Regional Fruit Research Station, Vegurle-416 516, dist. Sindhudurg (M.S.). Uniform eight months old grafts of cashew (V-4) were planted at $7 \mathrm{~m} \mathrm{x} \mathrm{7m} \mathrm{during} 2008$. The experiment was laid out in Randomized Block Design with three replications and eight treatments $\left(\mathrm{T}_{1}-100 \% \mathrm{~N}\right.$ as FYM, $\mathrm{T}_{1}+$ biofertilizers consortium $(\mathrm{BCF})(200 \mathrm{~g} /$ tree $), \mathrm{T}_{3}-50 \% \mathrm{~N}$ as $\mathrm{FYM}+\mathrm{BCF}(200 \mathrm{~g} /$ tree $)+$ rock phosphate, $\mathrm{T}_{4}-100 \% \mathrm{~N}$ as vermicompost $+\mathrm{BCF}\left(200 \mathrm{~g} /\right.$ tree $\left.^{-}\right), \mathrm{T}_{5}{ }^{-}$ recycling of organic residue with the addition of 20 per cent cow dung slurry (20\% weight of organic residue as cow dung slurry), $\mathrm{T}_{6}$ - In situ green manuring/green leaf manuring to meet $100 \%$ (retain litter + planting cowpea) $\mathrm{T}_{7}-25 \% \mathrm{~N}$ as FYM + recycling of organic residues + In situ green manuring/green leaf manuring $+\mathrm{BCF}(200 \mathrm{~g} /$ tree $)$ and $\mathrm{T}_{8}$ - control- recommended dose of fertilizer $+10 \mathrm{~kg}$ FYM). All the observations were recorded at appropriate stages. Similarly uniform package of practices were simultaneously followed. The data were statically analyzed as per procedure. Among the different organic manures tested, application of $50 \% \mathrm{~N}$ as FYM + BCF $(200 \mathrm{~g} /$ tree $)+$ rock phosphate $\left(\mathrm{T}_{3}\right)$ recorded maximum number of panicles $/ \mathrm{m}^{2}$ $\left(17.53 / \mathrm{m}^{2}\right)$ followed by $\mathrm{T}_{8}-$ control i.e. recommended dose of fertilizer $+10 \mathrm{~kg} \mathrm{FYM}\left(16.58 / \mathrm{m}^{2}\right)$ and $\mathrm{T}_{6}$ - In situ green manuring/green leaf manuring to meet $100 \%$ (retain litter + planting cowpea) $\left(16.32 / \mathrm{m}^{2}\right)$. While, application of recommended dose of fertilizer $+10 \mathrm{~kg}$ FYM $\left(\mathrm{T}_{8}-\right.$ control) recorded significantly the maximum mean pooled yield of $4.8 \mathrm{~kg} /$ tree and superior over the rest of the treatments.

Key words : Cashew, In situ leaf manuring, Organic manures, Apple weight, Yield

How to cite this article : Gajbhiye, R.C., Salvi, S.P. and Pawar, S.N. (2016).Effect of organic manures on growth and yield of cashew cv. VENGURLA-4 under Konkan region of Maharashtra. Asian J. Soil Sci., 11 (1) : 159-165 : DOI : 10.15740/HAS/AJSS/11.1/159-165. 